\title{
Development of a Low-Cost pH Meter for Liquid Chemical Fertilizers
}

\author{
Muhittin Yağmur Polat ${ }^{1, a, *}$, Abdullah Beyaz ${ }^{2, b}$, İbrahim Çilingir 2,c \\ ${ }^{1}$ Soil, Fertilizer and Water Resources Central Research Institute, 06172 Ankara, Turkey \\ ${ }^{2}$ Department of Agricultural Machinery and Technologies Engineering, Faculty of Agriculture, University of Ankara, 06110 Ankara, Turkey
} *Corresponding author

\begin{tabular}{l|l}
\hline A R T I C L E I N F O & A B S T R A C T \\
\hline Research Article & $\begin{array}{l}\text { Liquid chemical fertilizers are widely used in modern agriculture. The pH values of these fertilizers } \\
\text { are important in terms of their effectiveness in the field application and their effect on the soil-water } \\
\text { pH balance. Therefore, it is necessary to measure the pH and other properties of liquid fertilizers } \\
\text { with fast, practical and inexpensive methods. With the advancing technology, pH value has been } \\
\text { started to measure more accurately and efficiently with the help of low-cost devices. In this study, a } \\
\text { low-cost pH meter was developed using a low-cost pH sensor, an Arduino UNO R3 microcontroller } \\
\text { board, and a software written in the C/C++ programming language. The developed pH meter was } \\
\text { used to measure the pH values of liquid chemical fertilizers. Close variations were observed between } \\
\text { the values obtained from it and the values measured by an accredited, laboratory-type pH meter. } \\
\text { According to the pH measurements of the two pH meters, } \mathrm{R}^{2} \text { ranged } 88.1 \% \text { to } 99.3 \%, \text { average error } \\
\text { Accepted : } 20 / 03 / 2020 \\
\text { range } 0.14 \text { to } 0.28, \text { and average error percentage ranged } 1.56 \% \text { to } 6.81 \% \text { for three different types of } \\
\text { liquid fertilizers. In light of these results, it was shown that the developed low-cost pH meter can be } \\
\text { useful for practical pH measurement applications. }\end{array}$ \\
$\begin{array}{l}\text { Keywords: } \\
\text { pH meter } \\
\text { pH sensor } \\
\text { Microcontroller } \\
\text { Arduino }\end{array}$ &
\end{tabular}

Liquid fertilizers

\section{Sıvı Kimyasal Gübreler İçin Düşük Maliyetli Bir pH Metrenin Geliştirilmesi}

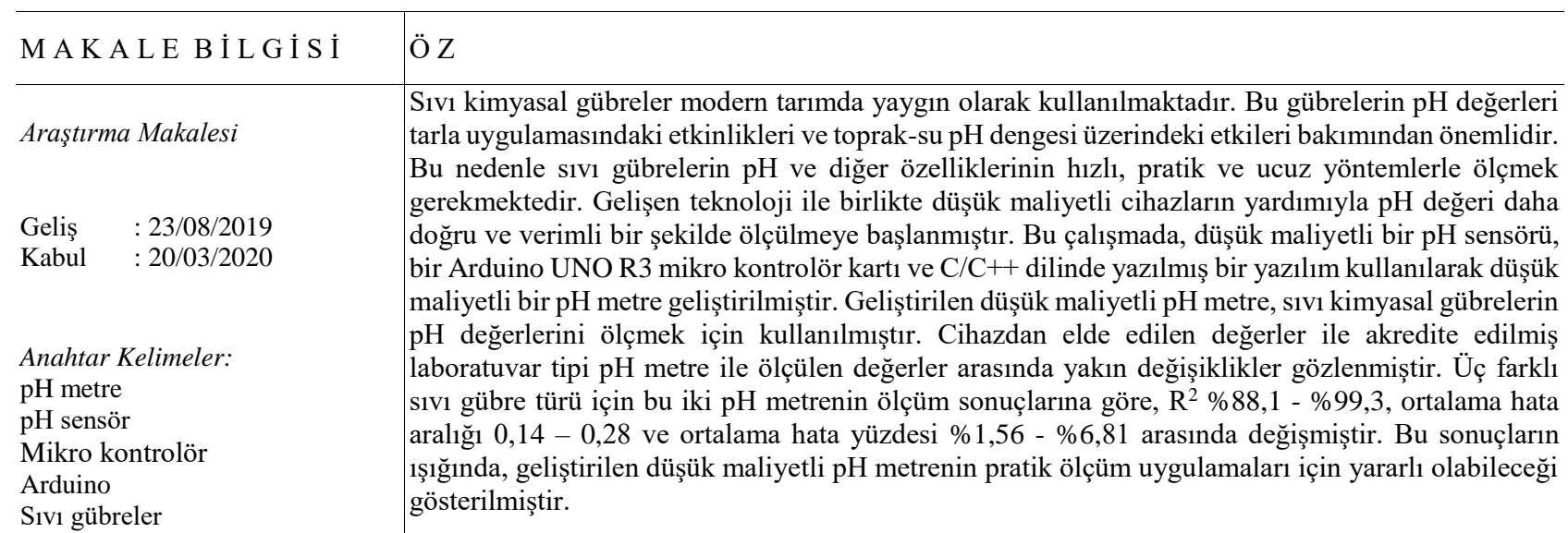

Siv1 gübreler gösterilmiştir. 


\section{Introduction}

The potential of Hydrogen $(\mathrm{pH})$ level is one of the main characteristics of any chemical solution. It plays a significant role in chemistry, pharmacy, medicine, agriculture, fish farming, and industries (Fatani et al., 2018). Accurate measurement and analysis of $\mathrm{pH}$ are needed for many applications ranging from industrial operations to biological processes requires. Additionally, the point of agricultural view, availability of nutrients for the plant, hinge on the $\mathrm{pH}$ content of the soil as well as the activity of soil bacteria. For these reasons, $\mathrm{pH}$ should be known to ensure the health of plants (Ramya and Palaniappan, 2012).

The $\mathrm{pH}$ value represents how many hydrogen ions $\left(\mathrm{H}^{+}\right)$ there are in a specific volume of a substance. This value shows the degree of acidity and ranges from 1 to 14 at $25^{\circ} \mathrm{C}$. The lower concentration of hydrogen ions will result in higher $\mathrm{pH}$ value. As shown in the Equation 1, the $\mathrm{pH}$ value is given by the negative logarithm of the relative hydrogen ion activity $(\mathrm{H}+)$ in a substance. $\mathrm{pH}$ value shows strong acidity as it approaches 0 , and strong alkalinity as it approaches 14 . When $\mathrm{H}^{+}$and $\mathrm{OH}^{-}$concentrations are equal, $\mathrm{pH}$ is neutral and is represented by the value 7. Changes in the $\mathrm{pH}$ level are not highly linear and measurements should be taken carefully to avoid instability (Harun et al., 2018, Lundin and Olli, 2017).

$$
\mathrm{pH}=-\log 10(\mathrm{H}+)
$$

Fertilization is one of the significant agricultural application, which is used to increase the productivity of agricultural products. The materials used as fertilizers are quite diverse. They are divided into two main groups as organic fertilizers and chemical fertilizers. Organic fertilizers are natural, and they have some organic properties such as farm manure, green manure, and compost. Chemical fertilizers are artificial fertilizers containing one or more nutrients (Demirtaş et al., 2005). Also, chemical fertilizers have some essential chemical properties like organic fertilizers as Potential of Hydrogen $(\mathrm{pH})$.

$\mathrm{pH}$ measurement is vital for chemical fertilizers. Technological achievements gave us a chance to develop low-cost $\mathrm{pH}$ measurement systems for this aim. One purpose of the "Industrial Revolution 4.0 " is to set free people to innovate by creating useful hardware and software. Industrial Revolution 4.0 also supports this viewpoint for agriculture (Urban, 2018).

According to Papadopoulos and Jannakoudakis (2016), modern devices equipped with microcontrollers are useful in measuring and collecting data. After the required analog signal conditioning, a microcontroller can be used to collect data from various sensors or any other analog source. The cost of microcontroller development cards has fallen and provides a low-cost platform to clarify the data collection process. Urban (2018) stated that experimental research projects were mostly done with the combination of purchased equipment, and this equipment could only be modified in laboratory conditions or production facilities focused on a single device. It is also noted that the Arduino is a crucial electronic prototype platform that versatile, easy to learn, inexpensive (\$20-30), and allows open- source hardware projects. A range of scientific instruments can be operated, including a Geiger detector, $\mathrm{pH}$ meter, oscilloscope, and DNA analysis (PCR).

Researches nowadays focused on improvement and the use of multipurpose electronic modules and programming. This approach can increase the flexibility, adaptability, and share ability of prototypes while reducing their size and costs. Under normal circumstances, device prototypes developed by chemists can't usually be anticipated to compete with high-end commercial devices, but the apparent advantages of prototyping with microcontroller boards and single-board computers can improve laboratory efficiency by developing creative technological solutions to challenges (Urban, 2018).

Universal electronic modules have been used to construct and run several scientific instruments including a radiation detector, $\mathrm{pH}$ meter, oscilloscope, syringe pump, and the polymerase chain reaction analyser (Urban, 2018). For example, Arduino Uno R3 and low-cost Arduino sensors can be used for chemical fertilizer $\mathrm{pH}$ measurements. The Arduino Uno R3 can be used to display measuring instruments such as thermometers and $\mathrm{pH}$ meters and is an open-source electronics platform based on easy-to-use hardware and software (Costa and Fernandes, 2018).

There is no need for expensive tools to make electronic instrumentation prototypes for chemical experiments. Today, prototyping and personalization of scientific instruments are eased by popular electronic modules. Currently, the most popular open-source MCB (MicroController Board) family is Arduino (Urban, 2018). Arduino is a system that has the advantages of using open source code, having a straightforward microprocessor circuit, and having the necessary software package for programming this circuit. One of the essential reasons why Arduino is popular is that it uses open-source code. In other words, these codes can be easily accessed (Koçak and Kırbaş, 2016).

Rolyi et al. (2019) developed a microcontroller-based digital soil $\mathrm{pH}$ meter using a low-voltage power supply, collector amplifier, Atmega328 microcontroller, etc. The performance of the $\mathrm{pH}$ meter was tested and found to be very stable and accurate. The device is found to be inexpensive and reliable to use compared to similar instruments in the international market. Moreover, they were found that the developed system was a better choice in terms of cost, portability, and design simplicity.

$\mathrm{A} \mathrm{pH}$ meter is a scientific instrument that measures the hydrogen-ion concentration (or $\mathrm{pH}$ ) in a solution, indicating its acidity or alkalinity (Harun et al., 2018). A $\mathrm{pH}$ meter consists of an electrode (measuring probe) connected to a device that measures and displays $\mathrm{pH}$ values (Dinambar et al., 2017). Jin et al. (2018) stated that pH determination is a necessary experiment in many chemistry laboratories. The working of a $\mathrm{pH}$ sensor is similar to a battery. Just like a battery, the measuring electrode which develops a potential directly related to the hydrogen ion concentration is connected to the positive terminal, while the reference electrode which provides a stable potential against which the measuring electrode potential can be compared is connected to the negative terminal (Oberoi et al., 2017). 
In the light of the literature, a low-cost $\mathrm{pH}$ meter was developed and used for $\mathrm{pH}$ measurements of liquid chemical fertilizers in this research. By this way, efficiency of a low cost device was determined and presented in the results section of the research.

\section{Material and Methods}

Development of an efficient system, which can measure the $\mathrm{pH}$ of liquid fertilizers and other liquids under controlled laboratory conditions with the low-cost parts is the main scope of the study. For this purpose, Arduino $\mathrm{pH}$ Meter was created with Arduino UNO R3 microcontroller board (Figure 1), a low-cost $\mathrm{pH}$ sensor (Figure 2), a character LCD, a keypad and an USB (Universal Serial Bus) battery unit. The Arduino UNO R3 card has Atmel ATmega328 microcontroller, six analog inputs that provide 10 bits of resolution, an USB connection, and a DC power input. Arduino Uno R3 can be powered by USB (D'Ausilio, 2012). The developed $\mathrm{pH}$ meter device, which was designed by using this feature, was supplied with an USB supported battery unit, and thus became portable.

Arduino cards have a pre-installed bootloader software in the microcontroller. These development cards can be used to evaluate analog and digital signals from sensors used for various purposes, and these evaluation results can be used as input for other systems. Before starting to work with Arduino, it is necessary to select the most suitable Arduino card (Beyaz and Beyaz, 2015). Arduino UNO is the right platform for some laboratory tests. The critical advantage of the Arduino concept is that hardware schemes and source codes are available free of charge for many projects in the developing large open source community, forums, and mailing lists (D’Ausilio, 2012). Moreover, Arduino's hardware is open source, many clones, and special-purpose cards are available (D'Ausilio, 2012). For the reasons mentioned above, Arduino UNO R3 was chosen as the microcontroller board used in the developed $\mathrm{pH}$ meter.

The low-cost $\mathrm{pH}$ sensor generates a negative signal for values between $\mathrm{pH} 0$ and $\mathrm{pH} 7$ with the help of its measurement card, the mean value of the sensor card, which is 0 Volt for $\mathrm{pH} 7$, was set to 2.5 Volt by using a potentiometer for adjusting the $\mathrm{pH}$ measurement values to the $0-5 \mathrm{~V}$ range. So that the analog inputs could be detected by Arduino (Table 1).

The measurement software which runs on the Arduino $\mathrm{pH}$ meter is written with the $\mathrm{C} / \mathrm{C}++$ programming language in Arduino IDE (Integrated Development Environment) and installed to Arduino UNO R3's ATmega328 microcontroller. By means of the software, analog $\mathrm{pH}$ signal detected by pin A0 (Analog 0) of the Arduino is converted to digital value with 10-bit resolution. This digital value then converted to $\mathrm{pH}$ value and displayed on the LCD. The conversion is performed with the calibration equation placed in the software. The algorithm of the software is given in Figure 3.

Table 1 Specifications of the low-cost $\mathrm{pH}$ sensor

\begin{tabular}{l|c}
\hline Measuring Range & $0-14 \mathrm{pH}$ \\
Accuracy & $\pm 0.1 \mathrm{pH}\left(25^{\circ} \mathrm{C}\right)$ \\
Measuring Temperature & $0-60^{\circ} \mathrm{C}$ \\
Response Time & $\leq 1 \mathrm{~min}$. \\
\hline
\end{tabular}

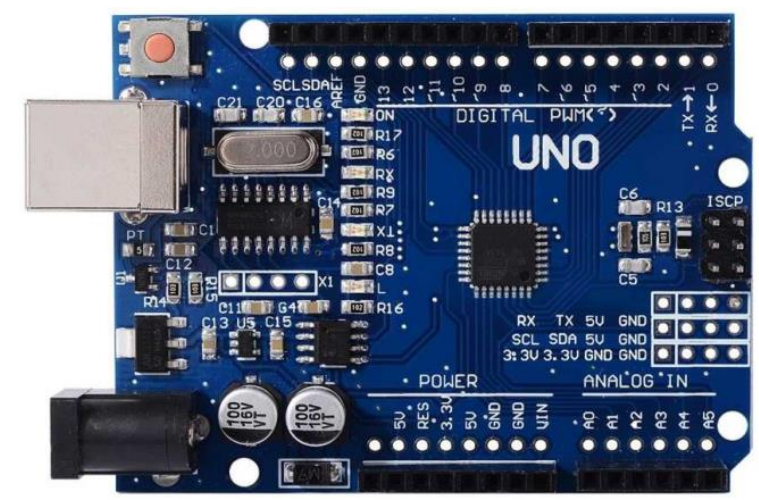

Figure 1. Arduino Uno R3 card

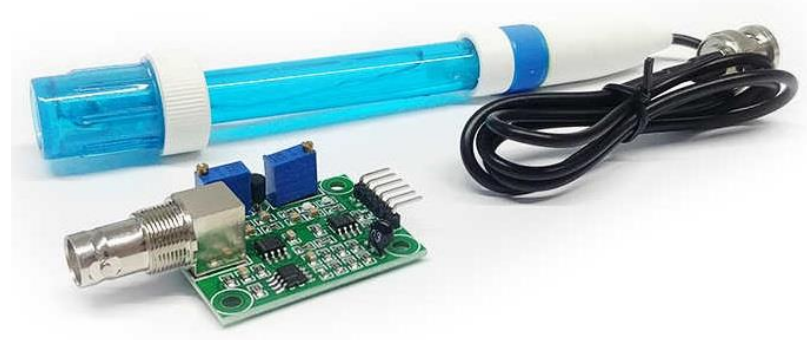

Figure 2 The $\mathrm{pH}$ sensor

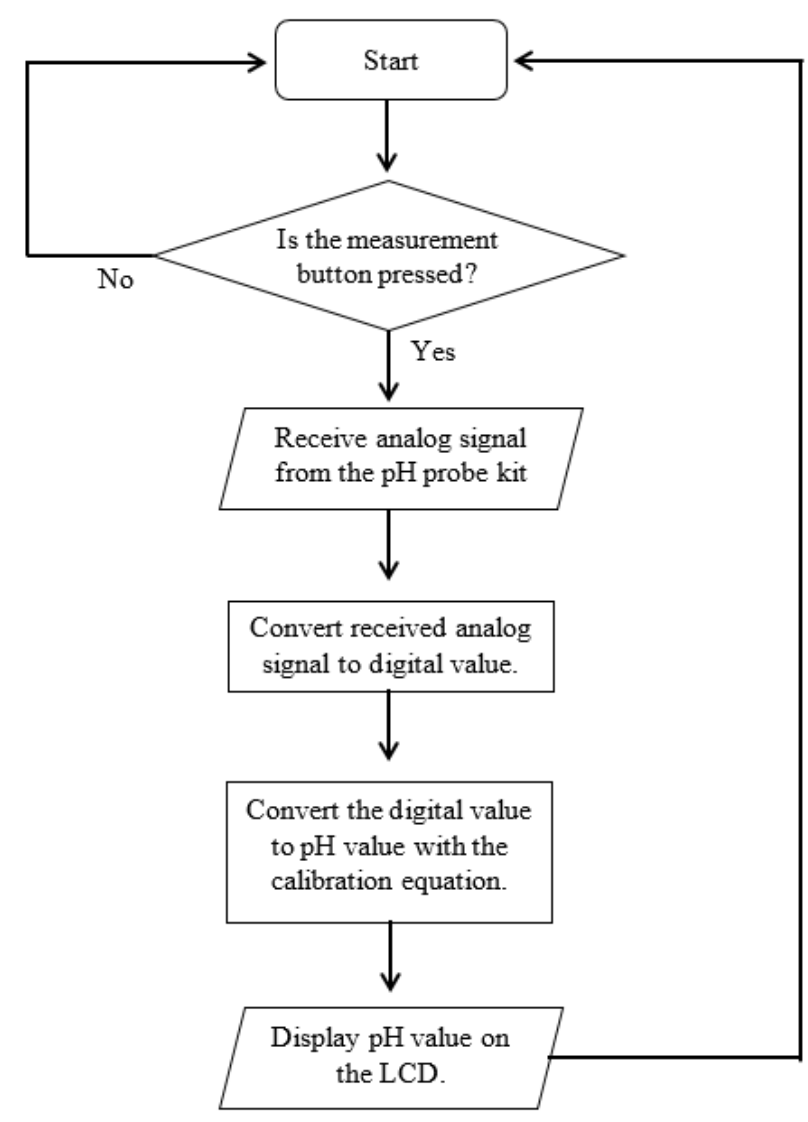

Figure 3. Algorithm of the measurement software

After completing the $\mathrm{pH}$ meter design (Figure 4 and 5), ten repetitive readings were performed in three different buffer solutions with 4.01, 7.00 and $10.01 \mathrm{pH}$ values at a controlled ambient temperature about $23.4^{\circ} \mathrm{C}$ and each buffer solution that were measured. With the temperature changes, the $\mathrm{pH}$ value of the buffer solutions can be changed. Because of this reason, the $\mathrm{pH}$ values were 
calculated at $23.4^{\circ} \mathrm{C}$ by linear interpolation technique from the temperature-pH change table given by the solutions of the manufacturer. As a result of the calculation, the $\mathrm{pH}$ values of the buffer solutions were found as 4.0680, 7.0064 and 10.0260, respectively. Then, regression analysis was performed between buffer solution values and analog values taken by microcontrollers from the $\mathrm{pH}$ sensor, by this way a regression coefficient, and a calibration curve was calculated (Figure 6). The coefficient was $\mathrm{R}^{2}=-0.99$; thus, a high relationship was found. The calculated function equation is given in the Equation 2. The equation was added to the program code to display the values in $\mathrm{pH}$ instead of raw analog data.

$$
y=21.404-0.0279 x
$$

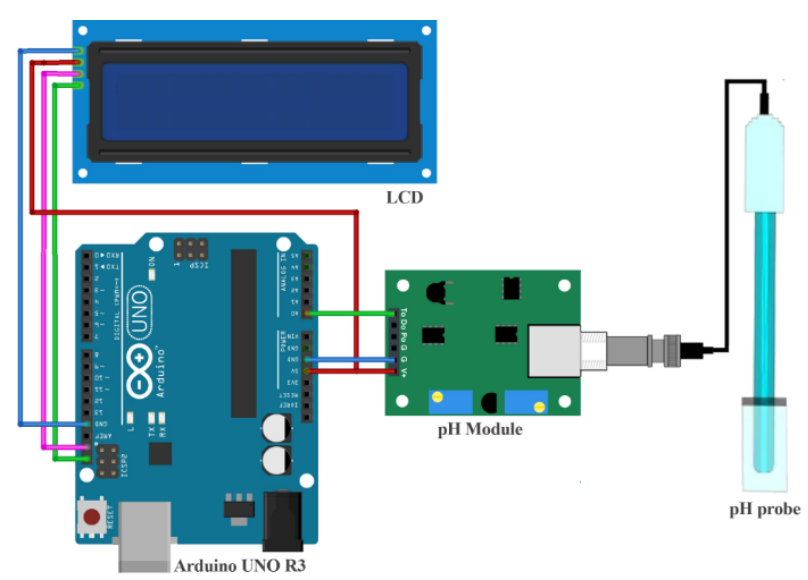

Figure 4. Schematic representation of the Arduino $\mathrm{pH}$ meter

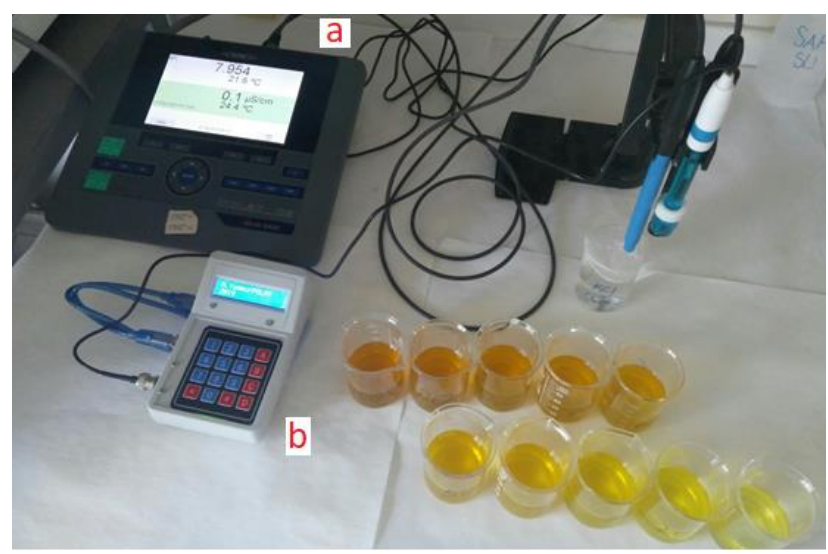

Figure 5. The WTW pH meter (a) and the Arduino $\mathrm{pH}$ meter (b)

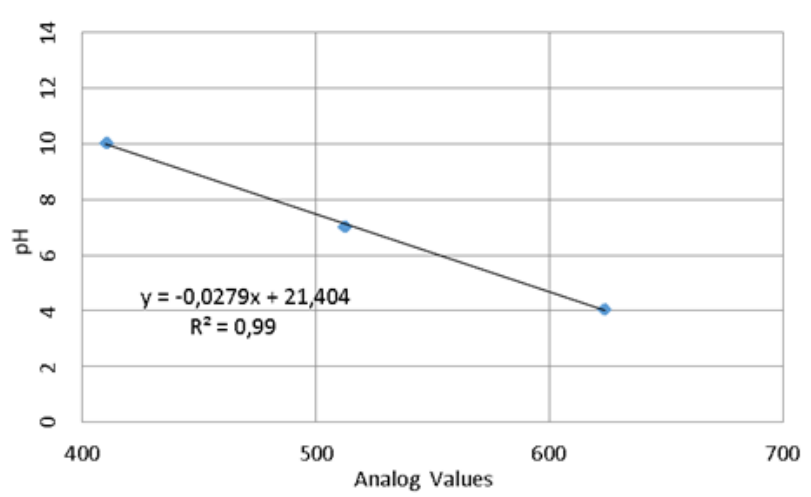

Figure 6 . The calibration curve
Two NPK and one Fe liquid chemical fertilizers were used for the experiments. The NPK1 liquid fertilizer has $10.5 \%$ Total $\mathrm{N}, 7.4 \% \mathrm{P}_{2} \mathrm{O}_{5}$, and $6.6 \% \mathrm{~K}_{2} \mathrm{O}$. The NPK2 liquid fertilizer has $10 \%$ Total $\mathrm{N}, 10 \% \mathrm{P}_{2} \mathrm{O}_{5}$, and $10 \% \mathrm{~K}_{2} \mathrm{O}$. Fe liquid fertilizer has 2\% EDTA chelated Fe. Mixtures with distilled water were made up to $100 \%$ so that each liquid fertilizer was present in a ratio of 10 to $100 \%$, and ten different mixtures were obtained. Each mixture was placed into three different bottles, so 30 samples were created for each fertilizer. Thus, a total of 90 samples were derived from three different fertilizers. An average of the three measurement replication was used as the last measurement in the statistical results.

The measurements made with the developed system were compared with the measurements of accredited, laboratory-type WTW (inoLab ${ }^{\circledR}$ Multi IDS 9420) $\mathrm{pH}$ meter by regression analysis. Each sample was measured three times at both devices. A regression model was formed by comparing the results of the regression equation and the measurement.

\section{Results and Discussion}

$\mathrm{pH}$ measurements between the WTW $\mathrm{pH}$ meter and the Arduino $\mathrm{pH}$ meter device for $10 \%$ to $100 \%$ for the first, second, and third NPK1 liquid fertilizer samples can be seen in Figure 7-9. The regression coefficients between the WTW $\mathrm{pH}$ meter and the Arduino $\mathrm{pH}$ meter device $\mathrm{pH}$ measurements found as 97.6\%, 98.4\%, 95.7\%, respectively. Similarly, $\mathrm{pH}$ measurements between the WTW pH meter and the Arduino $\mathrm{pH}$ meter device for $10 \%$ to $100 \%$ for the first, second, and third NPK2 liquid fertilizer samples can be seen in Figure 10-12. The regression coefficients of $\mathrm{pH}$ measurements have been found as $98.8 \%, 99.1 \%, 99.3 \%$, respectively. At last, $\mathrm{pH}$ measurements for $10 \%$ to $100 \%$ for the first, second, and third Fe liquid fertilizer samples can be seen in Figure 1315. The regression coefficients have been founded as $88.1 \%, 89.2 \%, 88.1 \%$, respectively. According to the $\mathrm{pH}$ measurements of the expensive WTW pH meter and lowcost Arduino $\mathrm{pH}$ meter, regression coefficients range between a minimum of $88.1 \%$ to a maximum of $99.3 \%$ for three different fertilizers.

Furthermore, $\mathrm{pH}$ measurements average values and error tables between the WTW pH meter and the Arduino $\mathrm{pH}$ meter for liquid fertilizers can be seen in Table 2. The average error and average error percentage of NPK1 fertilizer between the WTW pH meter and the Arduino $\mathrm{pH}$ meter device $\mathrm{pH}$ measurements found as $0.14,0.14,0.15$, and $1.59 \%, 1.56 \%, 1.69 \%$ respectively.

Also, the average error and average error percentage of NPK2 fertilizer between the WTW $\mathrm{pH}$ meter and the Arduino $\mathrm{pH}$ meter $\mathrm{pH}$ measurements found as $0.17,0.16$, 0.17 , and $3.27 \%, 3.10 \%, 3.19 \%$ respectively. At last, the average error and average error percentage of Fe fertilizer between the WTW $\mathrm{pH}$ meter and the Arduino $\mathrm{pH}$ meter $\mathrm{pH}$ measurements found as $0.26,0.27,028$, and $6.37 \%, 6.64 \%$, $6.81 \%$ respectively. According to the $\mathrm{pH}$ measurements of the expensive WTW pH meter and low-cost Arduino pH meter, the average error ranged between minimum 0.14 to maximum 0.28, and average error percentage ranged between minimum $1.56 \%$ to maximum $6.81 \%$ for three different liquid chemical fertilizers. 


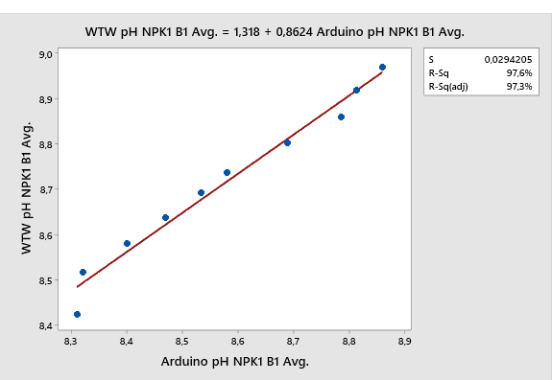

Figure 7. $\mathrm{pH}$ measurements between WTW pH meter and the Arduino $\mathrm{pH}$ meter for $10 \%$ to $100 \%$ for the first set of NPK1 liquid fertilizer samples

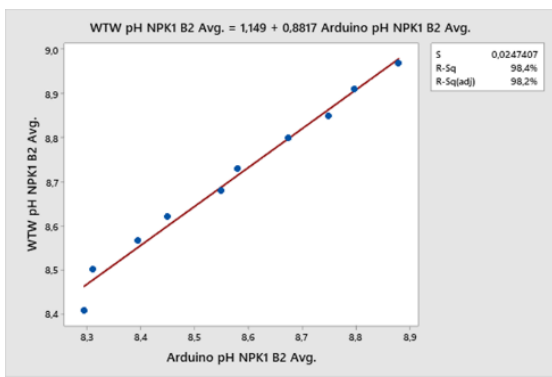

Figure 8. $\mathrm{pH}$ measurements between WTW $\mathrm{pH}$ meter and the Arduino $\mathrm{pH}$ meter for $10 \%$ to $100 \%$ for the second set of NPK1 liquid fertilizer samples

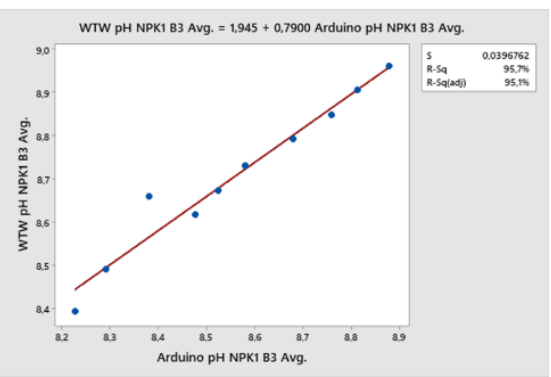

Figure 9. $\mathrm{pH}$ measurements between WTW pH meter and the Arduino $\mathrm{pH}$ meter for $10 \%$ to $100 \%$ for the third set of NPK1 liquid fertilizer samples

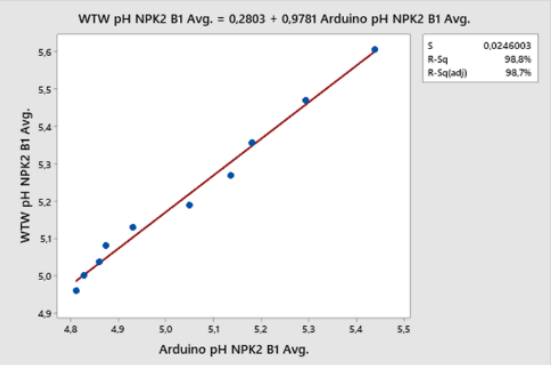

Figure 10. $\mathrm{pH}$ measurements between WTW $\mathrm{pH}$ meter and the Arduino $\mathrm{pH}$ meter for $10 \%$ to $100 \%$ for the first set of NPK2 liquid fertilizer samples

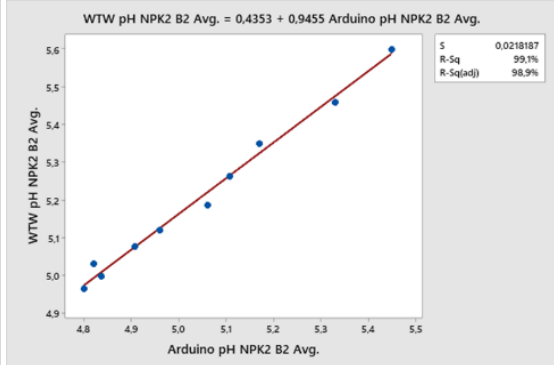

Figure 11. pH measurements between WTW pH meter and the Arduino $\mathrm{pH}$ meter for $10 \%$ to $100 \%$ for the second set of NPK2 liquid fertilizer samples

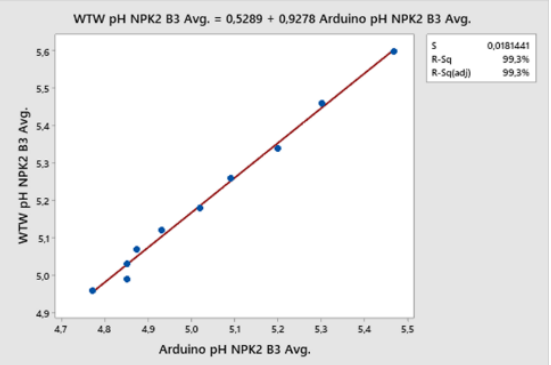

Figure 12. pH measurements between WTW pH meter and the Arduino $\mathrm{pH}$ meter for $10 \%$ to $100 \%$ for the third set of NPK2 liquid fertilizer samples

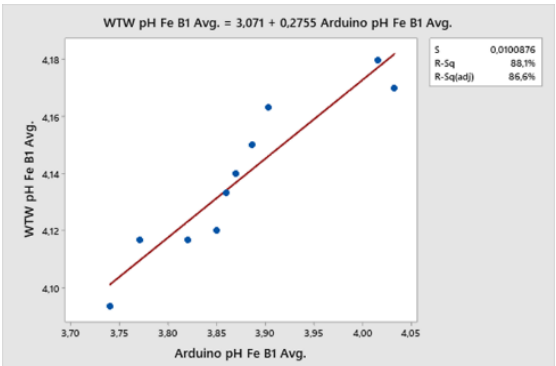

Figure 13. pH measurements between WTW pH meter and the Arduino $\mathrm{pH}$ meter for $10 \%$ to $100 \%$ for the first set of FE liquid fertilizer samples

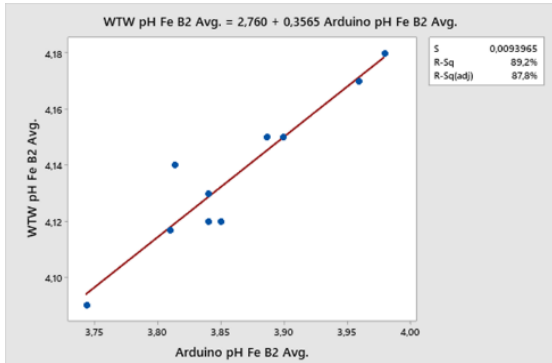

Figure 14. $\mathrm{pH}$ measurements between WTW $\mathrm{pH}$
meter and the Arduino $\mathrm{pH}$ meter for $10 \%$ to $100 \%$ for the second set of FE liquid fertilizer samples

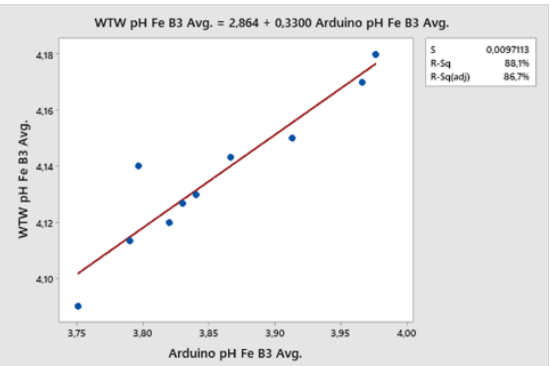

Figure 15. $\mathrm{pH}$ measurements between WTW $\mathrm{pH}$ meter and the Arduino $\mathrm{pH}$ meter for $10 \%$ to $100 \%$ for the third set of FE liquid fertilizer samples
In the literature, Kheiralla et al. (2016) worked on an on-the-go soil pH mapping system, and they developed its use in precision agriculture. Also, they compare it with the commercial FieldScout ${ }^{\mathbb{B}} \mathrm{pH} 110 \mathrm{pH}$ meter device, and they stated that the error of the developed device ranged between a minimum $0.43 \%$ and a maximum $10.1 \%$. In the research, the results show that the average error percentage range between a minimum of $1.56 \%$ to a maximum of 6.81\%. Additionally, Mashud et al. (2014) worked on a microcontroller-based digital $\mathrm{pH}$ meter. They compared it with the laboratory type PHM $83 \mathrm{pH}$ meter device, and they stated that the error of the developed device ranged between a minimum of 1.02 and a maximum of 11.04. In the research, results show that the average error range between a minimum of 0.14 to a maximum of 0.28 . It was observed that the error values we obtained from Arduino pH meter were lower than Mashud et al. (2014) and were found to be in a narrower error range than Mashud et al.
As a result, high precision, accuracy, and reliability are expected from laboratory-type devices. However, they are not suitable for outdoor use and are also expensive for farmers and field technicians. The cost of the developed Arduino $\mathrm{pH}$ meter is around $40 \$$, while the price of the acredited laboratory type WTW pH meter is around 2500 $\$$. The developed $\mathrm{pH}$ meter has portability because it is operated with a battery unit. In this way, it has the advantage for used in the places where the $\mathrm{pH}$ values of liquid chemical fertilizers should be known such as fertigation, aquaponics, hydroponics, and aeroponic techniques. Additionally, it can be used in other agricultural field studies where the $\mathrm{pH}$ value needs to be measured. However, the critical situation in this case is that the $\mathrm{pH}$ values vary with temperature and it is difficult to obtain constant temperature conditions under field conditions. For this reason, in low-cost devices to be developed for use in field conditions, temperature sensors and temperature compensation feature should be available. 
Table 2. $\mathrm{pH}$ measurements error table

\begin{tabular}{|c|c|c|c|c|c|c|c|c|c|c|c|}
\hline W-M1 & A-M1 & Error & Error $(\%)$ & W-M2 & A-M2 & Error & Error $(\%)$ & W-M3 & A-M3 & Error & Error $(\%)$ \\
\hline 8.42 & 8.31 & 0.11 & 1.35 & 8.41 & 8.29 & 0.11 & 1.35 & 8.39 & 8.23 & 0.17 & 1.99 \\
\hline 8.52 & 8.32 & 0.20 & 2.31 & 8.50 & 8.31 & 0.19 & 2.24 & 8.49 & 8.29 & 0.20 & 2.36 \\
\hline 8.58 & 8.40 & 0.18 & 2.10 & 8.57 & 8.39 & 0.17 & 2.02 & 8.66 & 8.38 & 0.28 & 3.23 \\
\hline 8.64 & 8.47 & 0.17 & 1.93 & 8.62 & 8.45 & 0.17 & 1.97 & 8.62 & 8.48 & 0.14 & 1.62 \\
\hline 8.69 & 8.53 & 0.16 & 1.84 & 8.68 & 8.55 & 0.13 & 1.50 & 8.67 & 8.52 & 0.15 & 1.73 \\
\hline 8.74 & 8.58 & 0.16 & 1.79 & 8.73 & 8.58 & 0.15 & 1.72 & 8.73 & 8.58 & 0.15 & 1.72 \\
\hline 8.80 & 8.69 & 0.11 & 1.29 & 8.80 & 8.67 & 0.13 & 1.44 & 8.79 & 8.68 & 0.11 & 1.29 \\
\hline 8.86 & 8.79 & 0.07 & 0.83 & 8.85 & 8.75 & 0.10 & 1.13 & 8.85 & 8.76 & 0.09 & 1.02 \\
\hline 8.92 & 8.81 & 0.11 & 1.20 & 8.91 & 8.80 & 0.11 & 1.27 & 8.91 & 8.81 & 0.09 & 1.05 \\
\hline \multirow[t]{2}{*}{8.97} & 8.86 & 0.11 & 1.23 & 8.97 & 8.88 & 0.09 & 1.00 & 8.96 & 8.88 & 0.08 & 0.93 \\
\hline & Average & 0.14 & 1.59 & & Average & 0.14 & 1.56 & & Average & 0.15 & 1.69 \\
\hline W-M4 & A-M4 & Error & Error $(\%)$ & W-M5 & A-M5 & Error & Error $(\%)$ & W-M6 & A-M6 & Error & Error $(\%)$ \\
\hline 5.61 & 5.44 & 0.17 & 2.97 & 5.60 & 5.45 & 0.15 & 2.68 & 5.60 & 5.47 & 0.13 & 2.32 \\
\hline 5.47 & 5.29 & 0.18 & 3.23 & 5.46 & 5.33 & 0.13 & 2.38 & 5.46 & 5.30 & 0.16 & 2.87 \\
\hline 5.36 & 5.18 & 0.18 & 3.30 & 5.35 & 5.17 & 0.18 & 3.36 & 5.34 & 5.20 & 0.14 & 2.62 \\
\hline 5.27 & 5.14 & 0.13 & 2.53 & 5.26 & 5.11 & 0.16 & 2.98 & 5.26 & 5.09 & 0.17 & 3.23 \\
\hline 5.19 & 5.05 & 0.14 & 2.70 & 5.19 & 5.06 & 0.13 & 2.44 & 5.18 & 5.02 & 0.16 & 3.09 \\
\hline 5.13 & 4.93 & 0.20 & 3.90 & 5.12 & 4.96 & 0.16 & 3.13 & 5.12 & 4.93 & 0.19 & 3.71 \\
\hline 5.08 & 4.87 & 0.21 & 4.07 & 5.08 & 4.91 & 0.17 & 3.35 & 5.07 & 4.87 & 0.20 & 3.88 \\
\hline 5.04 & 4.86 & 0.18 & 3.51 & 5.03 & 4.82 & 0.21 & 4.17 & 5.03 & 4.85 & 0.18 & 3.58 \\
\hline 5.00 & 4.83 & 0.17 & 3.47 & 5.00 & 4.84 & 0.16 & 3.20 & 4.99 & 4.85 & 0.14 & 2.81 \\
\hline \multirow[t]{2}{*}{4.96} & 4.81 & 0.15 & 3.02 & 4.96 & 4.80 & 0.16 & 3.29 & 4.96 & 4.77 & 0.19 & 3.83 \\
\hline & Average & 0.17 & 3.27 & & Average & 0.16 & 3.10 & & Average & 0.17 & 3.19 \\
\hline W-M7 & A-M7 & Error & Error (\%) & W-M8 & A-M8 & Error & Error $(\%)$ & W-M9 & A-M9 & Error & Error (\%) \\
\hline 4.18 & 4.02 & 0.16 & 3.91 & 4.18 & 3.98 & 0.20 & 4.78 & 4.18 & 3.98 & 0.20 & 4.86 \\
\hline 4.17 & 4.03 & 0.14 & 3.28 & 4.17 & 3.96 & 0.21 & 5.04 & 4.17 & 3.97 & 0.20 & 4.88 \\
\hline 4.16 & 3.90 & 0.26 & 6.24 & 4.15 & 3.90 & 0.25 & 6.02 & 4.15 & 3.91 & 0.24 & 5.70 \\
\hline 4.15 & 3.89 & 0.26 & 6.35 & 4.15 & 3.89 & 0.26 & 6.35 & 4.14 & 3.87 & 0.28 & 6.68 \\
\hline 4.14 & 3.87 & 0.27 & 6.52 & 4.14 & 3.81 & 0.33 & 7.89 & 4.14 & 3.80 & 0.34 & 8.29 \\
\hline 4.13 & 3.86 & 0.27 & 6.61 & 4.13 & 3.84 & 0.29 & 7.02 & 4.13 & 3.84 & 0.29 & 7.02 \\
\hline 4.12 & 3.85 & 0.27 & 6.55 & 4.12 & 3.84 & 0.28 & 6.80 & 4.13 & 3.83 & 0.30 & 7.19 \\
\hline 4.12 & 3.82 & 0.30 & 7.21 & 4.12 & 3.85 & 0.27 & 6.55 & 4.12 & 3.82 & 0.30 & 7.28 \\
\hline 4.12 & 3.77 & 0.35 & 8.42 & 4.12 & 3.81 & 0.31 & 7.45 & 4.11 & 3.79 & 0.32 & 7.86 \\
\hline \multirow[t]{2}{*}{4.09} & 3.74 & 0.35 & 8.63 & 4.09 & 3.74 & 0.35 & 8.48 & 4.09 & 3.75 & 0.34 & 8.31 \\
\hline & Average & 0.26 & 6.37 & & Average & 0.27 & 6.64 & & Average & 0.28 & 6.81 \\
\hline
\end{tabular}

W-M1: WTW pH NPK1 B1 Avg.; A-M1: Arduino pH NPK1 B1 Avg.; W-M2: WTW pH NPK1 B2 Avg.; A-M2: Arduino pH NPK1 B2 Avg.; W-M3: WTW pH NPK1 B3 Avg.; A-M3: Arduino pH NPK1 B3 Avg.; W-M4: WTW pH NPK2 B1 Avg.; A-M4: Arduino pH NPK2 B1 Avg.; W-M5: WTW pH NPK2 B2 Avg.; A-M5: Arduino pH NPK2 B2 Avg.; W-M6: WTW pH NPK2 B3 Avg.; A-M6: Arduino pH NPK2 B3 Avg. W-M7: WTW pH FE B1 Avg.; A-M7: Arduino pH FE B1 Avg.; W-M8: WTW pH FE B2 Avg.; A-M8: Arduino pH FE B2 Avg.;

W-M9: WTW pH FE B3 Avg.; A-M9: Arduino pH FE B3 Avg.

\section{References}

Beyaz A, Beyaz R. 2015. Traktörde Güvenlik Amaçlı Galvanik Deri Tepkisi Sensörü Kullanım Olanaklarının Belirlenmesi. Mühendislik Bilimleri ve Tasarım Dergisi. 3(3): 121-125.

Costa SC, Fernandes JC. 2018. Listening to pH. Journal of Chemical Education 96(2): 372-376 DOI: 10.1021/acs.jchemed.8b00641

D'Ausilio A. 2012. Arduino: A low-cost multipurpose lab equipment. Behavior Research Methods. 44(2): 305-313. DOI: $10.3758 / \mathrm{s} 13428-011-0163-\mathrm{Z}$

Demirtaş I, Nuri A, Arpacioğlu A, Harun K, Özkan C. 2005. Değişik organik kökenli gübrelerin kimyasal özellikleri. Derim. 22(2): 47-52

Dinambar BP, Sari DP, Irdayanti Y. 2017. Analysis of The Measurement of PH levels and levels of water clarity on the ship's robot. VOLT: Jurnal Ilmiah Pendidikan Teknik Elektro. 2(2): 133-142. DOI: 10.30870/volt.v2i2.1929

Fatani A, Kanawi A, Alshami H, Bensenouci A, Brahimi T, Bensenouci MA. 2018. Dual pH level monitoring and control using IoT application. 15th Learning and Technology Conference (L\&T). Jeddah, Saudi Arabia, 25-26 February 2018. Institute of Electrical and Electronics Engineers (IEEE), pp. 167-170. DOI: 10.1109/LT.2018.8368502
Harun Z, Reda E, Hashim H. 2018. Real time fish pond monitoring and automation using Arduino. IOP Conference Series: Materials Science and Engineering. 340(1): 012014. DOI: 10.1088/1757-899X/340/1/012014

Jin H, Qin Y, Pan S, Alam AU, Dong S, Ghosh R, Deen MJ. 2018. Open-source low-cost wireless potentiometric instrument for $\mathrm{pH}$ determination experiments. Journal of Chemical Education. 95(2): 326-330. DOI: 10.1021/acs.jchemed. $7 \mathrm{~b} 00479$

Kheiralla AF, El-Fatih WT, Abdellatief MK, El-Talib ZM. 2016. Design and development of on-the-go soil $\mathrm{pH}$ mapping system for precision agriculture. 2016 Conference of Basic Sciences and Engineering Studies (SGCAC). Khartoum, Sudan, 20-23 February 2016. Institute of Electrical and Electronic Engineers(IEEE), pp. 192-195. DOI: 10.1109/SGCAC.2016.7458028

Koçak Ç, Kırbaş İ. 2016. Arduino tabanlı prototip akıllı ev sistemi tasarımı. XVIII. Akademik Bilişim Konferansı (AB2016). Aydın, Türkiye, 30 Ocak - 5 Şubat 2016. Adnan Menderes Üniversitesi, pp. 387-392 
Lundin K, Olli O. 2017. Automated hydroponics greenhouse: Regulation of $\mathrm{pH}$ and nutrients. Bacherlor's Thesis. Kth Royal Institute of Technology, School Of Industrial Engineering And Management. Stockholm, Sweden.

Mashud MAA, Uddin MH, Islam MS. 2014. Design and implementation of microcontroller based digital soil $\mathrm{pH}$ meter. ULAB Journal of Science and Engineering. 5: 31-35

Oberoi A, Basavaraju S, Lekshmi S. 2017. Effective implementation of automated fertilization unit using analog pH sensor and Arduino. 2017 IEEE International Conference on Computational Intelligence and Computing Research (ICCIC). Tamil Nadu, India, 14-16 December 2017. Institute of Electrical and Electronic Engineers (IEEE), pp. 446-450. DOI: 10.1109/ICCIC.2017.8524170
Papadopoulos NJ, Jannakoudakis A. 2016. A chemical instrumentation course on microcontrollers and op amps. construction of a $\mathrm{pH}$ meter. Journal of Chemical Education, 93(7): 1323-1325. DOI: 10.1021/acs.jchemed.5b00743

Ramya V, Palaniappan B. 2012. Embedded pH data acquisition and logging. Advanced Computing. 3(1): 45-63. DOI: 10.5121/acij.2012.3104

Rolyi NA, Habiba U, Kabir H, Martuza KG, Akter F, Hafiz F, Haque MAS, Hoq M, Chowdhury AM. 2019. Design and Development of Microcontroller Based Digital Soil pH Meter. IOSR Journal of Electrical and Electronics Engineering, 14(2-I): 64-71. DOI: 10.9790/16761402016471

Urban PL. 2018. Prototyping instruments for the chemical laboratory using inexpensive electronic modules. Angewandte Chemie International Edition. 57(34): 1107411077. DOI: 10.1002/anie. 201803878 